\title{
Effects of Planting Density on Growth and Yield Attributes of Rubber Trees (Hevea brasiliensis)
}

\author{
Tran Thanh*, Nguyen Thanh Nhan, Vu Van Truong and Tran Dinh Minh \\ Department of Genetics and Plant Breeding, Rubber Research Institute of Vietnam, 236 Bis Nam Ky Khoi \\ Nghia Street, District 3, Ho Chi Minh City, Vietnam
}

\begin{abstract}
This study aimed to identify rubber clones, suitable for rubber-timber production. An experiment was established in randomized complete block design to evaluate the effects of two different planting densities on girth, girth increment, bark thickness, latex yield per tapping per tree $(\mathrm{g} / \mathrm{t} / \mathrm{t})$, incident of tapping panel dryness disease, and wood potential of nine rubber clones, including RRIV 2, RRIV 3, RRIV 4, RRIV 5, RRIV 107, PB 235, PB 260, PB 330, and RRIC 121. Data of girth, girth increment, bark thickness were collected in the $7^{\text {th }}$ year, prior to opening for tapping, and $17^{\text {th }}$ year of planting. In contrast, data of latex yield were collected in the $3^{\text {rd }}$ and the $11^{\text {th }}$ tapping year, and wood potential was compared based on the data collected in the $11^{\text {th }}$ tapping year. As a result, there were no significant interactions between clones and planting density in girth growth, latex yield, tapping panel dryness and bark thickness, and the first tapping panel (BO-1). There were no significant interactions between clone and planting density on girth growth, latex yield, tapping panel dryness, and bark thickness when these clones were tapped on the first tapping panel (BO1). Meanwhile, there were significant interactions between clones and planting density on girth growth, girth increment, and latex yield when the trees were tapped on the second tapping panel (BO-2). Statistical comparison of mean diameters at breast height and bole volume per tree of the same clones at two different planting densities showed that most of the studied clones gave significant differences.

ARTICLE INFO

Article history:

Received: 06 September 2021

Accepted: 15 November 2021

Published: 24 January 2022

DOI: https://doi.org/10.47836/pjtas.45.1.14

E-mail addresses:

tranthanhrriv@yahoo.com (Tran Thanh)

thanhnhan.rriv@gmail.com (Nguyen Thanh Nhan)

truongrriv@gmail.com (Vu Van Truong)

dminhrriv@gmail.com (Tran Dinh Minh)

$*$ Corresponding author

However, no significant differences resulted in the statistical comparison of the mean bole height of the same clones at two different planting densities. The total bole volume per hectare of all studied clones was larger at high planting density than at normal planting density. However, the bole volume per tree at high planting density was smaller
\end{abstract}


than that at normal planting density. Clone RRIC 121 could be considered a suitable clone for latex and timber productions. The favorable planting density for commercial timber production is high.

Keywords: Growth, Hevea brasiliensis, latex yield, planting density, timber production

\section{INTRODUCTION}

The rubber tree (Hevea brasiliensis Müll. Arg.) is a deciduous perennial tree producing natural rubber belonging to the Euphorbiaceae family. Hevea brasiliensis is a native species of the Amazon basin and was imported into tropical countries in Asia and Africa during the late $19^{\text {th }}$ century. In Vietnam, this species was brought into the country from Bogor (Indonesia) in 1897 by Alexandre Yersin (Lam et al., 2012). Since then, it has become one of the most important industrial crops and widely planted across the country. Currently, the total land planted with rubber trees in Vietnam is 932,400 hectares, and the natural rubber production is $1,226,100$ tonnes with an average latex yield of $1,682 \mathrm{~kg} / \mathrm{ha} /$ year. Most rubber plantations are in the Southeast region, followed by the Central Highlands, the Coastal region, and the newly developed areas in the Northern region.

Yield and timber production from the rubber tree is affected significantly by the size, the number, the distance, spatial arrangement of the adjacent trees, and planting density (Mäkinen, 1997). So far, the optimum planting density recommended for the rubber trees is 500-600 trees/ha is regardless of their genotypes or environmental conditions. At this density, the mature rubber trees would have enough space needed for their growth and development during their entire life cycles. Additionally, competition between the trees is in favor of the best production of dry rubber yield per hectare since planted in high densities, tree canopies could overlap, leading to the reduction of the size of the leaf canopy (Mäkinen, 1996), and the competition under the ground could also be high (Schroth, 1999). In rubber trees, stress induced by high tree densities was found to significantly reduce the girth and latex yield per tapping (grams/tree/ tapping) (Obouayeba et al., 2005; Webster \& Paardekooper, 1989). High planting densities contribute to delayed growth, taking a long time for the rubber trees to reach tappable girth and, therefore, the commencement of tapping.

Rubberwood is a by-product of rubber production as the rubber trees are mainly grown for latex and that this by-product is only available after 25-30 years when latex yield starts to decline significantly, and profit cannot compensate the cost of latex harvesting. At this time, replanting is required, and the old rubber trees need to be uprooted. At this stage, the byproduct of the rubberwood could be sold as firewood for a brick manufacturing factory or even burnt on the spot for land clearing. However, in recent years, this by-product has gained increasing attention when technical problems in processing and utilization of rubberwood have been overcome, and rubberwood can be used to manufacture 
a variety of products, especially furniture. That is why the combination of latex and wood production is becoming a popular trend in rubber-producing countries. Hence, one of the most important objectives in rubber breeding and selection is to produce rubber clones with high latex content, and high timber productivity, referred to as latex-timber clones. The present study aims to investigate the responses of growth, latex yield, and timber production of different rubber clones to two different planting densities to select the best rubber clones and their suitable planting density for latextimber production.

\section{MATERIALS AND METHODS}

\section{Experimental Design}

The experiment was established in randomized complete block design with two replicates for two factors, including rubber clone (9 rubber clones: RRIV 2, RRIV 3, RRIV 4, RRIV 5, RRIV 107, PB 235, PB 260, PB 330, and RRIC 121) and planting density (571 and 1,111 trees/ha). Each experimental block was 1.0 ha. These trials were established in Lai Khe Experimental Station of the Rubber Research Institute of Vietnam located at Lai Hung commune, Bau Bang district, Binh Duong province, which is considered the traditional rubber growing region of Vietnam. For the planting density of 571 trees/ha, the inter-row spacing was $7.0 \mathrm{~m}$, and the intra-row spacing was $2.5 \mathrm{~m}$; meanwhile, the respective spacing for the planting density of 1,111 trees/ha was 3.0 $\mathrm{m}$ and $3.0 \mathrm{~m}$.

\section{Measurements}

Growth measurements of rubber trees were taken annually in the immature stage, at which the girth of trees $(\mathrm{cm})$ was measured at the height of $150 \mathrm{~cm}$ above the ground level using a graded tape measure. Girths of the tapped trees were measured annually at the height of $100 \mathrm{~cm}$ above the ground level, and girth increment under tapping $(\mathrm{cm} /$ year) was thereby calculated. The girth was measured at two different stages: the $7^{\text {th }}$ year of planting (the last year of immature phase and the first tapping year) and the $17^{\text {th }}$ year of planting (the $11^{\text {th }}$ tapping year). The girth increment under tapping was determined as the mean increase in girth per year between the $7^{\text {th }}$ and $17^{\text {th }}$ years of planting.

Latex is normally harvested after $6-7$ years of planting when at least half of the total number of the trees in a plantation reaches the tappable girth of $50.0 \mathrm{~cm}$ or more at the height of $1.0 \mathrm{~m}$ above the ground. In order to harvest latex, the tappable rubber trees were opened for tapping at $1.3 \mathrm{~m}$ above the ground. The tapping system applied to harvest the annual latex yield of these two trials was the standardized one, $\mathrm{S} / 2 \mathrm{~d} 310 \mathrm{~m} / \mathrm{y}$, i.e., tapping the trunks in a half spiral ( $\mathrm{S} / 2)$ once every three days (d3) continuously for ten months of the year (10 $\mathrm{m} / \mathrm{y}$ ). On tapping days, latex was collected using the cup-coagulation method. Briefly, latex dripped into the plastic or ceramic cup equipped for each tapping tree, then, when latex flow stopped, 2-3\% acetic acid solution was added into the cups and stirred well to coagulate the latex. Coagulated rubber from each cup was labeled carefully, 
collected, and dried in the air for about one month before the dry rubber content of each rubber tree was weighed and calculated as gram per tree per tapping $(\mathrm{g} / \mathrm{t} / \mathrm{t})$. Latex yield was recorded for two different stages of the tapping phase: the third tapping year (9-year-old trees were tapped on their first tapping panel) and the $11^{\text {th }}$ tapping year (17-year-old trees were tapped on their second tapping panel, also referred to as 'BO-2 panel').

The thickness of virgin bark (mm) was measured prior to opening for tapping at $2-3 \mathrm{~cm}$ above the tapping panel using a bark gauge.

The bole height of rubber trees was measured using a laser hypsometer, namely Trimble LaserAce 1000 rangefinder (Trimble Navigation, USA). Bole volume per tree was calculated for each tree using stand volume models developed for rubber tree by Truong et al. (2003) as follows: V $=10^{(-3,668)} \times \mathrm{D}^{(1,629)} \times \mathrm{H}^{(0,921)}$ where $\mathrm{V}$ is the bole volume $\left(\mathrm{m}^{3} /\right.$ tree $), \mathrm{D}$ is the diameter measured at the breast height $(1 \mathrm{~m}, \mathrm{~cm})$, and $\mathrm{H}$ is the bole height (m), respectively. Latex yields were recorded at two different stages of the tapping phase: the third tapping year (9-year-old trees were tapped on their first tapping panel) and the $11^{\text {th }}$ tapping year (17-year-old trees were tapped on their second tapping panel, also referred to as 'BO-2 panel').

The data of the criteria mentioned above were recorded on 100 rubber trees per clone per replicate, which were marked carefully by paint.
Tapping panel dryness was investigated and counted on the trees, which showed total bark dryness in each replicate of treatment and expressed as a percentage.

\section{Statistical Analysis}

The data collected from these trials were analyzed using the Statistical Analysis System (SAS) statistical package (SAS Institute Inc., 1999), independent sample $t$-test to compare means between the planting densities, and analysis of variance (PROC ANOVA) was implemented for the analysis of the balanced data; meanwhile, general linear model (PROC GLM) was applied to analyze the unbalanced data.

\section{RESULTS AND DISCUSSION}

\section{Effects of Clones and Planting Density on Girth, Girth Increment, and Bark Thickness}

Data on the girth of the rubber clones planted at two different densities were collected and compared at different growth and development phases. In this experiment, girth and bark thickness were compared when the rubber clones were 7-year-old, right before these clones were subjected to latex harvesting, and when these clones were 17-year-old, at this time, these clones were under the $11^{\text {th }}$ tapping year. Girth increment per year calculated based on these two sets of data was referred to as girth increment under tapping in this study. As a result, a significant difference among clones was observed in girth at the $7^{\text {th }}$ and the $17^{\text {th }}$ year of planting, as well as in girth increment under the taping phase and bark thickness 
in both planting densities (Table 1). Girth growth of the clones in the normal density was greater than that in the high density. Among the clones, RRIV 2 had the highest girth at the $7^{\text {th }}$ and the $17^{\text {th }}$ year of planting as well as the highest girth increment under tapping in both planting densities. Statistical analysis revealed that both clone and planting density significantly affected girth, bark thickness, and girth increment under tapping phase $(P<0.001)$ when these clones were at a different stage (Table 2). However, the interaction between clone and planting density was found on girth $(P<0.001)$ and

Table 1

Girth growth (cm) and girth increment under tapping (cm/year) of studied clones under two different planting densities

\begin{tabular}{|c|c|c|c|c|c|c|}
\hline \multirow[b]{2}{*}{ Clones } & \multicolumn{3}{|c|}{ Planting density of 571 trees/ha } & \multicolumn{3}{|c|}{ Planting density of 1,111 trees/ha } \\
\hline & $\begin{array}{l}7^{\text {th }} \text { year of } \\
\text { planting }\end{array}$ & $\begin{array}{l}17^{\text {th }} \text { year of } \\
\text { planting }\end{array}$ & $\begin{array}{c}\text { Girth } \\
\text { increment }\end{array}$ & $\begin{array}{l}7^{\text {th }} \text { year of } \\
\text { planting }\end{array}$ & $\begin{array}{l}17^{\text {th }} \text { year of } \\
\text { planting }\end{array}$ & $\begin{array}{c}\text { Girth } \\
\text { increment }\end{array}$ \\
\hline RRIV 2 & $54.7^{\mathrm{a}}$ & $74.5^{\mathrm{a}}$ & $2.00^{\mathrm{bcd}}$ & $44.5^{\mathrm{a}}$ & $64.5^{\mathrm{a}}$ & $2.68^{\mathrm{a}}$ \\
\hline RRIV 3 & $46.9^{\text {cde }}$ & $65.6^{\mathrm{cd}}$ & $1.80^{\mathrm{cd}}$ & $38.1^{\mathrm{b}}$ & $52.3^{\mathrm{e}}$ & $1.14^{\mathrm{f}}$ \\
\hline RRIV 4 & $49.0^{\mathrm{bc}}$ & $65.3^{\mathrm{d}}$ & $1.64^{\mathrm{d}}$ & $40.0^{\mathrm{ab}}$ & $55.3^{\mathrm{d}}$ & $1.40^{\text {ef }}$ \\
\hline RRIV 5 & $50.7^{\mathrm{b}}$ & $72.5^{\mathrm{ab}}$ & $2.19^{\mathrm{bc}}$ & $38.6^{\mathrm{b}}$ & $58.2^{\mathrm{bc}}$ & $1.73^{\text {cde }}$ \\
\hline RRIV 107 & $48.1^{\mathrm{cd}}$ & $75.9^{\mathrm{a}}$ & $2.79^{\mathrm{a}}$ & $40.2^{\mathrm{ab}}$ & $58.8^{\mathrm{b}}$ & $2.24^{\mathrm{abc}}$ \\
\hline PB 235 & $48.4^{\mathrm{cd}}$ & $70.3^{\mathrm{bc}}$ & $2.23^{\mathrm{bc}}$ & $40.2^{\mathrm{ab}}$ & $64.0^{\mathrm{a}}$ & $2.04^{\text {bcd }}$ \\
\hline PB 260 & $45.7^{\mathrm{e}}$ & $69.9^{\mathrm{bcd}}$ & $2.42^{\mathrm{ab}}$ & $38.5^{\mathrm{b}}$ & $56.0^{\mathrm{cd}}$ & $1.61^{\mathrm{def}}$ \\
\hline PB 330 & $47.7^{\text {cde }}$ & $72.6^{\mathrm{ab}}$ & $2.48^{\mathrm{ab}}$ & $37.6^{\mathrm{b}}$ & $59.1^{\mathrm{b}}$ & $1.93^{\text {cde }}$ \\
\hline RRIC 121 & $46.3^{\mathrm{de}}$ & $67.5^{\mathrm{cd}}$ & $2.07^{\mathrm{bcd}}$ & $39.3^{\mathrm{ab}}$ & $62.3^{\mathrm{a}}$ & $2.52^{\mathrm{ab}}$ \\
\hline CV (\%) & 1.77 & 2.81 & 9.11 & 5.9 & 1.67 & 11.91 \\
\hline$F$-value & $20.15^{* *}$ & $7.23^{* *}$ & $6.44^{* *}$ & $1.54^{\mathrm{ns}}$ & $34.79^{* * *}$ & $9.84^{* *}$ \\
\hline
\end{tabular}

Note. Means within columns with the same letter(s) are not significantly different at the 0.05 probability level. $\mathrm{CV}=$ Coefficient of variation; ${ }^{\mathrm{ns}}$ Non-significant; ${ }^{* *}$ Significant at 0.01 probability level; ${ }^{* * *}$ Significant at 0.001 probability level

Table 2

Effects of clone and planting density to growth and bark thickness

\begin{tabular}{lccccc}
\hline \multirow{2}{*}{$\begin{array}{l}\text { Source of } \\
\text { variations }\end{array}$} & df & \multicolumn{4}{c}{ Mean square } \\
\cline { 2 - 5 } & & $\begin{array}{c}\text { Girth after } 7^{\text {th }} \\
\text { year of planting }\end{array}$ & $\begin{array}{c}\text { Girth after 17 } \\
\text { year of planting }\end{array}$ & $\begin{array}{c}\text { Girth increment } \\
\text { under tapping }\end{array}$ & Bark thickness \\
\hline Replication & 1 & $3.81551^{\text {ns }}$ & $2.88434^{\text {ns }}$ & $0.01174^{\text {ns }}$ & $0.02054^{\text {ns }}$ \\
Clone & 8 & $20.68630^{* * *}$ & $46.68405^{* * *}$ & $0.48846^{* * *}$ & $0.64070^{* * *}$ \\
Density & 1 & $717.16840^{* * *}$ & $1189.44514^{* * *}$ & $1.16280^{* * *}$ & $1.46410^{* * *}$ \\
Clone x Density & 8 & $2.72425^{\text {ns }}$ & $15.49042^{* * *}$ & $0.29140^{* *}$ & $0.13225^{* *}$ \\
Error & 17 & 3.03136 & 2.33128 & 0.05666 & 0.01746 \\
Mean & - & 44.11199 & 64.66475 & 2.26979 & 6.09782 \\
CV $(\%)$ & - & 3.94683 & 2.36119 & 10.48218 & 2.16672 \\
\hline
\end{tabular}

$\mathrm{df}=$ Degrees of freedom; $\mathrm{CV}=$ Coefficient of variation; ${ }^{\mathrm{n}}$ Non-significant; ${ }^{* *}$ Significant at 0.01 probability level; ${ }^{* * *}$ Significant at 0.001 probability level 
bark thickness $(P<0.01)$ girth increment under tapping $(P<0.01)$ when they were in the $17^{\text {th }}$ year of planting, indicating that girth, girth increment, and bark thickness of the rubber clones seemed to be affected significantly by the planting densities during the tapping phase.

This study showed that the rubber trees planted in low density grew better than the trees planted in high density; therefore, they had larger circumference regardless of their ages. Better girth at the $7^{\text {th }}$ year after planting indicated that trees planted at low density had a better growth rate than the trees planted closely. The previous study reported that during the tapping phase, the growth rate of the tree decreased significantly, and the growth during the immature stage played the key role in determining its future yields (Webster \& Paardekooper, 1989) since low density during the immature phase supported the growth rate of those trees (Rodrigo et al., 1995). In addition, the finding of this study conformed to the finding reported by Naji and Sahri (2012) that trees, which were closely planted had slow growth rates.

\section{Effects of Clone and Planting Density on Latex Yield and Tapping Panel Dryness}

The mean latex yield of the studied clones at the $3^{\text {rd }}$ and the $11^{\text {th }}$ years of tapping in both planting densities were significantly different (Table 3 ). The results showed that the grams/tree/tapping yield $(\mathrm{g} / \mathrm{t} / \mathrm{t})$ at the $3^{\text {rd }}$ year of tapping of clone RRIV 4 was significantly greater than that of the other clones when this clone was planted in high planting densities. Meanwhile, RRIC 121 could be considered the best yielding clone

Table 3

Latex yield (grams/tree/tapping, g/t/t) and tapping panel dryness (TPD, \%) of studied clones under two different planting densities

\begin{tabular}{lcccccc}
\hline & \multicolumn{2}{c}{ Planting density of 571 trees/ha } & \multicolumn{2}{c}{ Planting density of 1,111 trees/ha } \\
\cline { 2 - 7 } Clones & $\begin{array}{c}3^{\text {rd }} \text { year of } \\
\text { tapping }\end{array}$ & $\begin{array}{c}11^{\text {th }} \text { year of } \\
\text { tapping }\end{array}$ & TPD & $\begin{array}{c}3^{\text {rd }} \text { year of } \\
\text { tapping }\end{array}$ & $\begin{array}{c}11^{\text {th }} \text { year of } \\
\text { tapping }\end{array}$ & TPD \\
\hline RRIV 2 & $52.88^{\mathrm{ab}}$ & $54.2^{\mathrm{bc}}$ & $13.39^{\mathrm{b}}$ & $43.89^{\mathrm{bc}}$ & $26.4^{\mathrm{cd}}$ & $10.09^{\mathrm{b}}$ \\
RRIV 3 & $48.61^{\mathrm{abc}}$ & $53.6^{\mathrm{bc}}$ & $9.99^{\mathrm{b}}$ & $29.08^{\mathrm{e}}$ & $35.5^{\mathrm{bc}}$ & $16.45^{\mathrm{ab}}$ \\
RRIV 4 & $59.17^{\mathrm{a}}$ & $52.1^{\mathrm{dc}}$ & $15.50^{\mathrm{b}}$ & $56.37^{\mathrm{a}}$ & $30.1^{\mathrm{bcd}}$ & $26.09^{\mathrm{ab}}$ \\
RRIV 5 & $54.84^{\mathrm{ab}}$ & $55.7^{\mathrm{b}}$ & $9.93^{\mathrm{b}}$ & $47.64^{\mathrm{b}}$ & $34.7^{\mathrm{bc}}$ & $8.68^{\mathrm{b}}$ \\
RRIV 107 & $56.11^{\mathrm{a}}$ & $50.1^{\mathrm{d}}$ & $12.01^{\mathrm{b}}$ & $34.67^{\mathrm{de}}$ & $23.8^{\mathrm{d}}$ & $21.57^{\mathrm{ab}}$ \\
PB 235 & $54.38^{\mathrm{ab}}$ & $40.5^{\mathrm{e}}$ & $15.70^{\mathrm{b}}$ & $43.59^{\mathrm{bc}}$ & $30.1^{\mathrm{bcd}}$ & $28.01^{\mathrm{ab}}$ \\
PB 260 & $47.78^{\mathrm{abc}}$ & $49.8^{\mathrm{d}}$ & $14.86^{\mathrm{b}}$ & $37.61^{\mathrm{cd}}$ & $36.1^{\mathrm{bc}}$ & $43.27^{\mathrm{a}}$ \\
PB 330 & $43.18^{\mathrm{bc}}$ & $58.7^{\mathrm{a}}$ & $27.06^{\mathrm{a}}$ & $33.08^{\mathrm{de}}$ & $37.5^{\mathrm{b}}$ & $27.14^{\mathrm{ab}}$ \\
RRIC 121 & $38.34^{\mathrm{c}}$ & $59.1^{\mathrm{a}}$ & $8.58^{\mathrm{b}}$ & $31.54^{\mathrm{de}}$ & $49.4^{\mathrm{a}}$ & $16.00^{\mathrm{ab}}$ \\
\hline CV (\%) & 9.68 & 2.68 & 31.51 & 7.80 & 12.29 & 56.84 \\
$F$-value & $3.74^{*}$ & $33.32^{* * *}$ & $3.07^{\mathrm{ns}}$ & $16.32^{* * *}$ & $6.54^{* *}$ & $1.48^{\mathrm{ns}}$ \\
\hline
\end{tabular}

Note. Means within columns with the same letter(s) are not significantly different at the 0.05 probability level. $\mathrm{CV}=$ Coefficient of variation; TPD $=$ Tapping panel dryness; ${ }^{n}$ Non-significant; ${ }^{*}$ Significant at 0.05 probability level; ${ }^{* *}$ Significant at 0.01 probability level; ${ }^{* * *}$ Significant at 0.001 probability level 
in gram/tree/tapping at the $11^{\text {th }}$ year of both planting densities. Regarding tapping panel dryness (TPD), there was no significant difference in TPD incidence among the clones in both planting densities.

It was revealed that there was no interaction between clones and planting densities on grams/tree/tapping yield at the $3^{\text {rd }}$ year of tapping $(P>0.05)$ (Table $4)$, which suggested that planting density seemed to have similar effects on all studied clones during the tapping years on the first tapping panel (BO-1). Similarly, no marked link between the density of planting and the occurrence of tapping panel dryness $(P$ $>0.05$ ) indicated that the effect of planting density on clones was seemly similar (Table 4). This finding agreed with the previous study, which also showed no clear interaction between clone and planting density in TPD incidence (Obouayeba et al., 2005). Conversely, there was an interaction between clones and planting densities in grams/tree/tapping yield at the $11^{\text {th }}$ year of tapping $(P<0.01)$ (Table 4$)$, indicating that clones seemed to be affected by the planting density during the years of tapping on the second tapping panel (BO-2).

Although the yield per tree decreases, higher yields of timber production per hectare can be obtained by employing higher planting densities (Obouayeba et al., 2005), and optimum tree densities have been identified in consideration of this fact. Nevertheless, before implementing this cultural practice, it is very important to consider the costs of planting materials, planting practices, and maintenance of the plantations during the immature and mature phases, as well as costs of latex harvest and manufacture because these costs could be higher when a greater number of trees are maintained under high densities.

\section{Effects of Clones and Planting Densities on Timber Production}

Diameter at Breast Height (DBH) and Bole Height (BH). In general, a negative correlation between DBH value and planting density was revealed, as shown in Figure

Table 4

Effects of clone and planting density to latex yield and tapping panel dryness

\begin{tabular}{|c|c|c|c|c|}
\hline \multirow{2}{*}{$\begin{array}{l}\text { Source of } \\
\text { variations }\end{array}$} & \multirow[b]{2}{*}{$\mathrm{df}$} & \multicolumn{3}{|c|}{ Mean square } \\
\hline & & $\begin{array}{l}\text { Individual yield of } 3^{\text {rd }} \text { year } \\
\text { of tapping }\end{array}$ & $\begin{array}{l}\text { Individual yield of } 11^{\text {th }} \text { year } \\
\text { of tapping }\end{array}$ & $\begin{array}{l}\text { Tapping panel } \\
\text { dryness (TPD) }\end{array}$ \\
\hline Replication & 1 & $0.93767^{\mathrm{ns}}$ & $45.11361^{\mathrm{ns}}$ & $979.48134^{\mathrm{ns}}$ \\
\hline Clone & 8 & $210.50972^{* * *}$ & $136.35948^{* * *}$ & $199.77482^{\text {ns }}$ \\
\hline Density & 1 & $1063.73823^{* * *}$ & $3259.26810^{* * *}$ & $548.96490^{\mathrm{ns}}$ \\
\hline Clone x Density & 8 & $35.83646^{\mathrm{ns}}$ & $42.71591^{* *}$ & $90.32911^{\mathrm{ns}}$ \\
\hline Error & 17 & 16.62380 & 10.741229 & 194.54552 \\
\hline Mean & - & 45.15250 & 43.24500 & 18.01722 \\
\hline CV (\%) & - & 9.02991 & 7.578637 & 77.41458 \\
\hline
\end{tabular}

$\mathrm{CV}=$ Coefficient of variation; ${ }^{\mathrm{ns}}$ Non-significant; ${ }^{* *}$ Significant at 0.01 probability level; ${ }^{* * *}$ Significant at 0.001 probability level 
1a. Table 5 shows that the mean DBH calculated for each clone was smaller as the planting density increased from 571 trees/ ha to 1,111 trees/ha. The results showed that, in the same planting density, the mean DBH was significantly different among the nine studied clones (Table 5). However, a

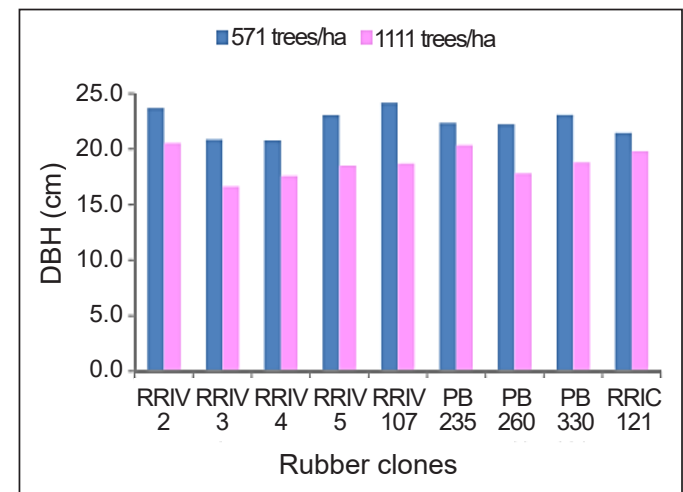

(a) statistical comparison of mean DBH of the same clones planted at two different planting densities revealed significant differences in five out of nine studied clones (Table 6). These results indicated that intra-row and inter-row spacing significantly affected the diameter of the rubber clones. The trees

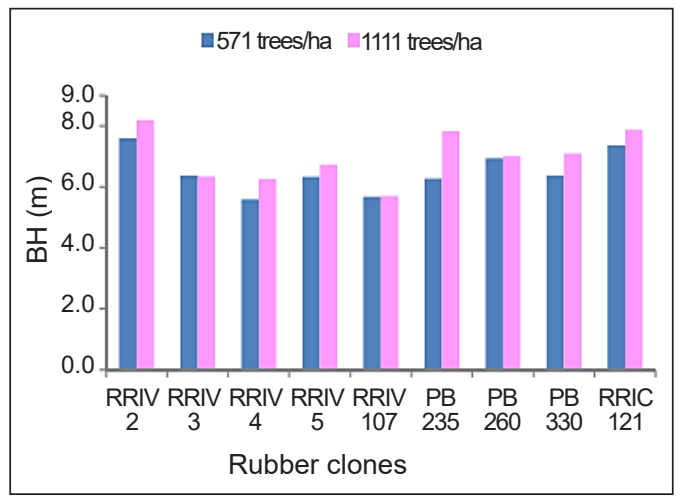

(b)

Figure 1. Effect of two different planting densities to diameter at breast height (a) and bole height (b) of the studied clones

Table 5

Diameter at breast height (DBH) and bole height (BH) of studied clones under two different planting densities

\begin{tabular}{lcccccccc}
\hline & \multicolumn{3}{c}{ Planting density of 571 trees/ha } & \multicolumn{2}{c}{ Planting density of 1,111 trees/ha } \\
\cline { 2 - 9 } Clones & \multicolumn{2}{c}{ DBH $(\mathrm{cm})$} & \multicolumn{2}{c}{ BH $(\mathrm{m})$} & \multicolumn{2}{c}{ DBH $(\mathrm{cm})$} & \multicolumn{2}{c}{ BH $(\mathrm{m})$} \\
\cline { 2 - 9 } & Mean & SD & Mean & SD & Mean & SD & Mean & SD \\
\hline RRIV 2 & $23.69^{\mathrm{a}}$ & 5.93 & $7.6^{\mathrm{a}}$ & 2.84 & $20.49^{\mathrm{a}}$ & 4.56 & $8.2^{\mathrm{a}}$ & 2.46 \\
RRIV 3 & $20.87^{\mathrm{cd}}$ & 3.80 & $6.4^{\mathrm{c}}$ & 2.10 & $16.90^{\mathrm{e}}$ & 2.26 & $6.4^{\mathrm{bc}}$ & 1.58 \\
RRIV 4 & $20.81^{\mathrm{d}}$ & 4.32 & $5.6^{\mathrm{d}}$ & 1.33 & $17.72^{\mathrm{d}}$ & 3.14 & $6.3^{\mathrm{bc}}$ & 1.39 \\
RRIV 5 & $23.12^{\mathrm{ab}}$ & 5.56 & $6.4^{\mathrm{c}}$ & 1.96 & $18.54^{\mathrm{bc}}$ & 2.67 & $6.8^{\mathrm{abc}}$ & 1.49 \\
RRIV 107 & $24.15^{\mathrm{a}}$ & 5.39 & $5.7^{\mathrm{d}}$ & 2.21 & $18.85^{\mathrm{b}}$ & 3.27 & $5.7^{\mathrm{c}}$ & 2.15 \\
PB 235 & $22.39^{\mathrm{bc}}$ & 5.37 & $6.3^{\mathrm{c}}$ & 2.14 & $20.45^{\mathrm{a}}$ & 4.24 & $7.9^{\mathrm{ab}}$ & 1.75 \\
PB 260 & $22.25^{\mathrm{bcd}}$ & 4.12 & $7.0^{\mathrm{b}}$ & 2.27 & $17.89^{\mathrm{cd}}$ & 2.55 & $7.0^{\mathrm{abc}}$ & 1.67 \\
PB 330 & $23.11^{\mathrm{ab}}$ & 5.71 & $6.4^{\mathrm{c}}$ & 2.10 & $18.38^{\mathrm{b}}$ & 3.47 & $7.1^{\mathrm{abc}}$ & 1.60 \\
RRIC 121 & $21.48^{\mathrm{cd}}$ & 3.69 & $7.4^{\mathrm{a}}$ & 1.96 & $20.20^{\mathrm{a}}$ & 4.05 & $7.9^{\mathrm{ab}}$ & 2.37 \\
\hline CV (\%) & 2.81 & - & 2.97 & - & 1.67 & - & 9.40 & - \\
$F$-value & $7.23^{* *}$ & - & $24.91^{* * *}$ & - & $34.79^{* * *}$ & - & $3.29^{*}$ & - \\
\hline
\end{tabular}

Note. Means within columns with the same letter(s) are not significantly different at the 0.05 probability level. $\mathrm{CV}=$ Coefficient of variation; $\mathrm{DBH}=$ Diameter at breast height; $\mathrm{BH}=$ Bole height; $\mathrm{SD}=$ Standard deviation; ${ }^{*}$ Significant at 0.05 probability level; ${ }^{* *}$ Significant at 0.01 probability level; ${ }^{* * *}$ Significant at 0.001 probability level 
Table 6

Independent t-test comparing the diameter at breast height, bole height and bole volume per tree of the same clones between two planting densities

\begin{tabular}{lccccccccccc}
\hline \multirow{2}{*}{ Clones } & Planting & \multicolumn{3}{c}{ Diameter at breast height } & \multicolumn{3}{c}{ Bole height } & \multicolumn{3}{c}{ Bole volume per tree } \\
\cline { 3 - 12 } & density & $t$-value & $\operatorname{Pr}>|t|$ & SE & $t$-value & $\operatorname{Pr}>|t|$ & SE & $t$-value & $\operatorname{Pr}>|t|$ & SE \\
\hline RRIV 2 & D1-D2 & 0.65 & 0.5137 & 0.7506 & -1.77 & 0.0790 & 0.3668 & -0.56 & 0.5769 & 0.0222 \\
RRIV 3 & D1-D2 & 2.96 & $\mathbf{0 . 0 0 3 8}$ & 0.5246 & 1.49 & 0.1401 & 0.2833 & 2.54 & $\mathbf{0 . 0 1 2 3}$ & 0.0116 \\
RRIV 4 & D1-D2 & -0.04 & 0.9659 & 0.5846 & -1.04 & 0.3003 & 0.1653 & -0.33 & 0.7400 & 0.0093 \\
RRIV 5 & D1-D2 & 1.92 & $\mathbf{0 . 0 4 9 6}$ & 0.7776 & 0.01 & 0.9908 & 0.2638 & 1.90 & $\mathbf{0 . 0 4 9 8}$ & 0.0151 \\
RRIV 107 & D1-D2 & 4.21 & $<\mathbf{0 . 0 0 0 1}$ & 0.6594 & -1.42 & 0.1584 & 0.2914 & 3.02 & $\mathbf{0 . 0 0 3 2}$ & 0.0166 \\
PB 235 & D1-D2 & 0.80 & 0.4270 & 0.7030 & -0.69 & 0.4943 & 0.2904 & 0.10 & 0.9182 & 0.0156 \\
PB 260 & D1-D2 & 1.95 & $\mathbf{0 . 0 4 7 6}$ & 0.5967 & 0.09 & 0.9309 & 0.2870 & 1.91 & $\mathbf{0 . 0 4 8 2}$ & 0.0141 \\
PB 330 & D1-D2 & 2.14 & $\mathbf{0 . 0 3 4 4}$ & 0.7218 & -0.87 & 0.3887 & 0.2668 & 1.98 & $\mathbf{0 . 0 4 5 7}$ & 0.0161 \\
RRIC 121 & D1-D2 & 1.80 & 0.0744 & 0.4763 & -1.06 & 0.2931 & 0.2610 & 0.41 & 0.6848 & 0.0117 \\
\hline
\end{tabular}

Note. Bold type indicates significant difference at the 0.05 probability level. SE $=$ Standard error. D1 and D2 represent normal and high planting densities, respectively

with the largest diameter were found among trees planted at the density of 571 trees/ha, while the trees with the smallest diameter were seen in the high planting density of 1,111 trees/ha, as clearly shown in RRIV 107, RRIV 3, PB 330, PB 260, and RRIV 5 . This result agreed with the previous studies, which reported that an increase in circumference of a tree depended on the growth ring and, therefore, depended on the increase of the diameter (Cockerham, 2004; Lei et al., 1997; Scott et al., 1998). Wider spacing supported plants to grow better, resulting in larger stem girth.

The mean $\mathrm{BH}$ of the studied rubber clones increased when these rubber clones were planted more densely (Figure 1b), suggesting that the $\mathrm{BH}$ of the rubber trees could have a was positive correlation with the tree density. The results showed that mean bole height was significantly different among nine rubber clones when these clones were planted in the same density (Table 5).
Generally, intra-row and inter-row spacing significantly affected the bole height of the rubber trees. Those trees with the largest $\mathrm{BH}$ and smallest $\mathrm{BH}$ were found among the rubber trees planted in high density and low density. A similar result was reported and explained that in densely plantations, competition for light and less space for expansion promoted plants to grow in height (Nasir et al., 2006). However, statistical analysis revealed that the difference in the mean $\mathrm{BH}$ of the rubber trees of the same rubber clone was not statistically significant regardless of the planting densities (Table 6).

\section{Bole Volume per Tree and per Hectare.}

Bole volume was calculated for each tree using the stand volume model developed for rubber trees by Truong et al. (2003). Total wood production/hectare was calculated for each rubber clone in each planting density using data of individual trees. The mean bole volume $(\mathrm{BV})$ per tree was smaller in 
planting density of 571 trees/ha than that in planting density of 1,111 trees/ha (Figure $2 a)$, suggesting there was possibly a negative correlation between $\mathrm{BV}$ of individual trees and planting density. In contrast, the total bole volume (BV) per hectare was greater in trials of 1,111 trees/ha than that in trials of 571 trees/ha irrespective of the rubber clones

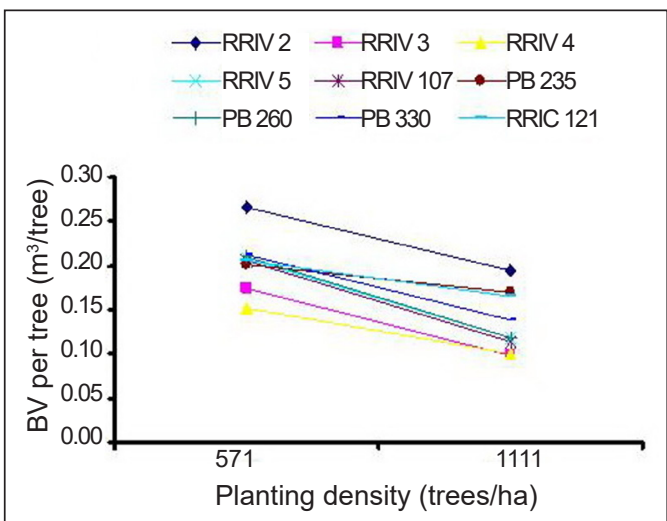

(a)
(Figure 2b), indicating that there was likely a positive correlation between total BV per hectare and planting density. In addition, the results showed that the mean bole volume per tree and hectare was significantly different among the rubber clones regardless of the planting density (Table 7). The independent sample $t$-test proved that there

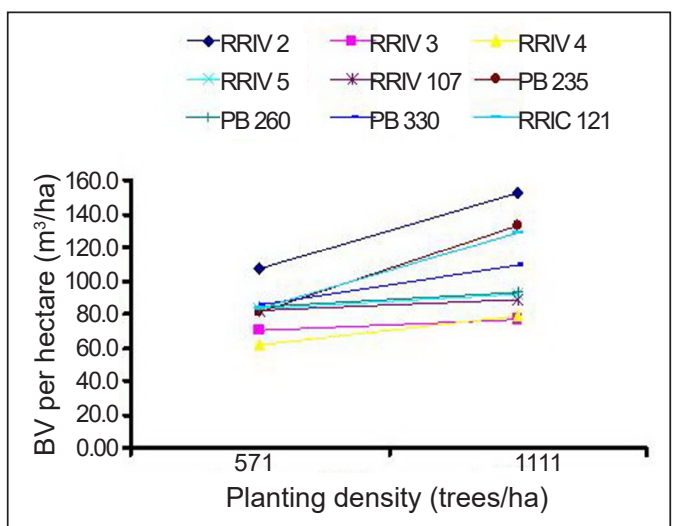

(b)

Figure 2. Effect of two different planting densities to bole volume per tree (a) and total bole volume per hectare (b) of nine rubber clones

Table 7

Bole volume per tree and per hectare of studied clones at two different planting densities based on bole height and diameter at breast height

\begin{tabular}{lcccc}
\hline \multirow{2}{*}{ Clones } & \multicolumn{2}{c}{ Planting density of 571 trees/ha } & \multicolumn{2}{c}{ Planting density of 1,111 trees/ha } \\
\cline { 2 - 5 } & $\begin{array}{c}\text { Bole volume per tree } \\
\left(\mathrm{m}^{3} / \text { tree }\right)\end{array}$ & $\begin{array}{c}\text { Bole volume per } \\
\text { hectare }\left(\mathrm{m}^{3} / \mathrm{ha}\right)\end{array}$ & $\begin{array}{c}\text { Bole volume per tree } \\
\left(\mathrm{m}^{3} / \text { tree }\right)\end{array}$ & $\begin{array}{c}\text { Bole volume per } \\
\text { hectare }\left(\mathrm{m}^{3} / \mathrm{ha}\right)\end{array}$ \\
\hline RRIV 2 & $0.270^{\mathrm{a}}$ & $106.70^{\mathrm{a}}$ & $0.195^{\mathrm{a}}$ & $152.35^{\mathrm{a}}$ \\
PB 330 & $0.215^{\mathrm{b}}$ & $85.05^{\mathrm{b}}$ & $0.140^{\mathrm{bc}}$ & $108.95^{\mathrm{bcd}}$ \\
PB 260 & $0.215^{\mathrm{b}}$ & $84.60^{\mathrm{b}}$ & $0.120^{\mathrm{bc}}$ & $92.65^{\mathrm{cd}}$ \\
RRIV 5 & $0.210^{\mathrm{b}}$ & $83.70^{\mathrm{b}}$ & $0.120^{\mathrm{bc}}$ & $92.15^{\mathrm{dc}}$ \\
RRIC 121 & $0.205^{\mathrm{bc}}$ & $82.85^{\mathrm{b}}$ & $0.165^{\mathrm{bc}}$ & $129.00^{\mathrm{abc}}$ \\
RRIV 107 & $0.205^{\mathrm{bc}}$ & $82.20^{\mathrm{b}}$ & $0.115^{\mathrm{bc}}$ & $88.50^{\mathrm{d}}$ \\
RRIV 3 & $0.175^{\mathrm{cd}}$ & $70.10^{\mathrm{c}}$ & $0.095^{\mathrm{c}}$ & $77.10^{\mathrm{d}}$ \\
RRIV 4 & $0.155^{\mathrm{d}}$ & $61.05^{\mathrm{c}}$ & $0.100^{\mathrm{c}}$ & $79.15^{\mathrm{d}}$ \\
PB 235 & $0.205^{\mathrm{bc}}$ & $80.90^{\mathrm{b}}$ & $0.170^{\mathrm{ab}}$ & $132.50^{\mathrm{ab}}$ \\
\hline CV (\%) & 6.18 & 5.44 & 16.17 & 15.11 \\
$F$-value & $12.06^{* * *}$ & $15.28^{* *}$ & $4.90^{* *}$ & $5.50^{* *}$ \\
\hline
\end{tabular}

Note. Means within columns with the same letter(s) are not significantly different at the 0.05 probability level. $\mathrm{CV}=$ Coefficient of variation; ${ }^{* *}$ Significant at 0.01 probability level; ${ }^{* * *}$ Significant at 0.001 probability level 
was a statistically significant difference in the bole volume per tree recorded for those rubber clones of RRIV 107, RRIV 3, PB 330, PB 260, and RRIV 5 between two planting densities $(P<0.05)$ (Table 6$)$. A greater total bole volume per hectare of each studied clone was found in high tree density compared to normal tree density (Table 7). These results were supported by findings reported in previous studies (Naji \& Sahri, 2012; Wei et al., 2005), which revealed that better wood biomass could be obtained from intensive planting density for commercial production. In short, high planting density is a better choice for commercial rubberwood production. Although low planting density could help obtain bigger and heavier individual trees, it could not help to compensate for the difference in biomass brought by the total bole volume per hectare in densely planted populations. In addition to the findings mentioned above, this study also revealed that clones RRIV 2 were suitable for timber production when planted in both densities while RRIC 121 and PB 235 were suitable for timber production in high planting density as these clones had higher BV per hectare than the other clones.

\section{CONCLUSION}

Performances of the rubber clones in terms of girth, girth increment, bark thickness, latex yield, and rubberwood production were significantly affected by planting density and rubber clones, while these two factors did not affect the tapping incident panel dryness disease. There was no interaction between rubber clones and planting density on girth measured on the $7^{\text {th }}$ year of planting (immature stage) and latex yield when tapped on the first tapping panel (BO-1, the third tapping year). Meanwhile, there were significant interactions between rubber clones and tree spacing on the girth increment as well as the latex yield when the trees were under tapping on the second tapping panel (BO-2, the $11^{\text {th }}$ tapping year).

In high planting density, RRIV 2 and RRIC 121 were recorded as the suitable clones for timber production and latex yield, respectively. Regarding both latex and timber productions, RRIC 121 was recorded as the best clone that gave the high latex yield and the high timber production in the normal or high planting density.

Variations in the diameter measured at the breast height and the bole height due to planting density resulted in a significant reduction in the wood potential of the less dense rubber plantations. The diameter of $H$. brasiliensis measured at breast height was greater at normal planting density. Meanwhile, the bole height in high planting density was positively correlated with the number of rubber trees per hectare. As a result, planting the rubber trees more densely is a favorable solution for the commercial production of rubber timber.

\section{ACKNOWLEDGMENTS}

The authors would like to express their gratitude to Mr. Phan Thanh Dung, Director of Rubber Research Institute of Vietnam, for his permission to present this paper. Thanks also go to the technicians of the Department 
of Genetics and Plant Breeding of Rubber Research Institute of Vietnam for their contribution to this research.

\section{REFERENCES}

Cockerham, S. T. (2004). Irrigation and planting density affect river red gum growth. California Agriculture, 58(1), 40-43. https://doi. org/10.3733/ca.v058n01p40

Lam, L. V., Thanh, T., Trang, L. T. T., Truong, V. V., Lam, H. B., \& Tuy, L. M. (2012). Hevea germplasm in Vietnam: Conservation, characterization, evaluation and utilization. In M. Caliskan (Ed.), Genetic diversity in plants (pp. 433-456). InTech Publisher. https://doi. org/10.5772/35086

Lei, H., Gartner, L. B., \& Milota, M. R. (1997). Effect of growth rate on the anatomy, specific gravity, and bending properties of wood from 7-yearold red alder (Alnus rubra). Canadian Journal of Forest Research, 27(1), 80-85. https://doi. org/10.1139/x96-165

Mäkinen, H. (1996). Effect of inter tree competition on biomass production of Pinus sylvestris (L.) halfsib families. Forest Ecology and Management, 86(1-3), 105-112. https://doi.org/10.1016/S03781127(96)03788-7

Mäkinen, H. (1997). Possibilities of competition indices to describe competitive differences between Scots pine families. Silva Fennica, 31(1), 43-52. https://doi.org/10.14214/sf.a8509

Naji, H. R., \& Sahri, M. H. (2012). Intra- and inter-clonal tree growth variations of Hevea brasiliensis. Journal of Forestry Research, 23(3), 429-434. https://doi.org/10.1007/s11676012-0280-2

Nasir, M. A., Aziz, A., Mohar, T. A., Rehman, M. A., \& Ahmad, S. (2006). Effect of planting distance on tree growth and fruit quality of shamber grapefruit under agro climatic conditions of
Sargodha. Journal of Agricultural Research, 44(4), 353-358.

Obouayeba, S., Dian, K., Boko, A. M. C., Gnagne, Y. M., \& Ake, S. (2005). Effect of planting density on growth and yield productivity of Hevea brasiliensis Muell. Arg. clone PB 235. Journal of Rubber Research, 8(4), 257-270.

Rodrigo, V. H. L., Nugawela, A., Pathiratna, L. S. S., Waidyanatha, U. P. S., Samaranayake, A. C. I., Kodikara, P. B., \& Weeralal, J. L. K. (1995). Effect of plant density on growth, yield, and yield related factors and profitability of rubber (Hevea brasiliensis Muell. Arg.). Journal of Rubber Research Institute of Sri Lanka, 76, 55-71.

SAS Institute Inc. (1999). SAS/STAT user's guide (version 8.01). SAS Institute.

Schroth, G. (1999). A review of below ground interactions in agroforestry, focusing on mechanisms and management options. Agroforestry Systems, 43(1), 5-34. https://doi. org/10.1023/A:1026443018920

Scott, W., Meade, R., \& Leon, R. (1998). Planting density and tree-size relations in coast Douglasfir. Canadian Journal of Forest Research, 28(1), 74-78. https://doi.org/10.1139/x97-190

Truong, V. V., Lam, L. V., Tuy, L. M., \& Hoa, T. T. T. (2003, November 12-14). An approach for estimation of wood volume of the main stem of rubber stands [Paper presentation]. Proceedings of the Workshop on Rubber, Wood, Croping and Research, Bangkok, Thailand.

Webster, C. C., \& Paardekooper, E. C. (1989). The botany of the rubber tree. In C. C. Webster \& W. J. Baulkwill (Eds.), Rubber (pp. 57-84). Longman Scientific and Technical.

Wei, H. Y., Wang, Y., Wang, Z., \& Yan, X. (2005). Effect of planting density on plant growth and camptothecin content of Camptotheca acuminate seedlings. Journal of Forestry Research, 16(2), 137-139. https://doi.org/10.1007/BF02857907 